\author{
Andrés CAÑIZÁLEZ
}

Andrés Bello Catholic University

\title{
THE PRESIDENT IS THE MESSAGE: \\ POPULISM AND PERSONALITY POLITICS \\ IN VENEZUELAN GOVERNMENT \\ COMMUNICATIONS (2000-2010) ${ }^{1}$
}

ABSTRACT This paper analyzes government communications in Venezuela under the administration of Hugo Chávez, whose focal point is the "Bolivarian Revolution". The communications model is heavily characterized by populism and personality politics, as concluded when analyzing three significant moments for the democratic governability of Hugo Chávez's administration: his ratification or re-election in office in the years 2000, 2004 and 2006. The elaboration of public policy plans in presidential addresses was studied given the importance of communications within government strategies.

KEY WORDS Populism, personality politics, Hugo Chávez, media, government communications, Venezuela.

\section{GOVERNMENT AND COMMUNICATIONS}

The greater part of contemporary literature on political communications clearly identifies two main fields of action within this discipline. First, election campaigns are featured as the natural realm of political communication. However, government communications are considered at the same time as the other fundamental column of a structure

\footnotetext{
1 This article was submitted for publication before the death of Hugo Chávez.
} 
where governments, media and political parties coexist. In this context, the Political Government Communications ${ }^{2}$ are considered the specific course of action. The nature of government action requires communication strategies which will - on the one hand - enable the visualization of its own administration in terms of accomplishments, and at the same time, the ability to face and symbolically offset the errors, scandals or mistakes which could damage the administration.

Moreover, public communications spread significantly due to the popularity gained by radio and electronic media, especially by the television since the 1960 's. This opened a new interaction space for political actions representative of the 20th century. ${ }^{3}$ The very own nature of television imposes new codes to communication strategies which are aimed at influencing the political environment. For this reason, campaigns increasingly become more personal and entail a particular emotional connotation.

This new communications scenario has characterized the political and government actions since the second half of the 20th century. It includes a redefinition of the relationship government - governed, since a characteristic of the modern political communications is to continually sound out the state of public opinion: it is about knowing what the average citizen thinks. For the modern leader talks to the citizens. Although mass society with its overcrowded cities does not allow direct contact, the leader knows the citizens' opinions about their government through serious and systematic investigations. This new configuration in communications results in the fact that the government official will value the things that are important for regular people. ${ }^{4}$ The caricatures aimed at discrediting political communications present the political leader as a fool or a person who lacks personality and acts according to surveys and polls. This is not the reality for the people who exercise a genuine leadership, who appeal to public opinion studies as an additional tool added to their own proposals, consultations with experts, political assessments, etc. However, the communicative dimension has also given a conversational twist to the exercise of power: The leader is there to drive, to direct. The change is in the fact that (s) he cannot do so in an authoritative monologue, as the previous prophets did. The leader must also listen. ${ }^{5}$

When referring to the particularities of political government communications, some authors define different types of communication strategies according to the public administration context. In this sense and in accordance to Felipe Noguera the following types can be set out:

a) A reactive communication, where the government reacts - with or without anticipation - to the occurring events and must communicate; b) A proactive type of communication, where communications are initiatives used strategically to promote the government's

2 H. Vega, 'La comunicación de gobierno e Internet' in R. Izurieta, C. Arterton, R. Perina (comps.), Estrategias de comunicación para gobiernos, Buenos Aires 2005, pp. 131-186.

3 S. Berrocal, 'Una aproximación a la nueva retórica del líder político televisivo: acciones, cualidades y discurso', DOXA Comunicación, $\mathrm{N}^{\circ} 2$ (2004), pp. 53-67.

4 J. Durán, 'Estrategias de comunicación política' in R. Izurieta, C. Arterton, R. Perina (comps.), Estrategias de comunicación..., pp. 23-76.

5 Ibid., p. 34. 
agenda; c) An accounting type of communication, since it seeks to settle ('account for') the administration's accomplishments in the minds of the electorate. ${ }^{6}$

The literature about the relationship between government and communication media highlights several presidents of the United States of America who set a milestone in this field. Woodrow Wilson's arrival to the White House (1913-21) set a standard in the institutionalism of political government communications by creating the first public information office. However, this milestone was set within a communications model that went over the government, because it dealt with a communications scheme based on the presidential figure. This scheme was established by Franklin Delano Roosevelt (1933-45) who applied a self-oriented policy above government institutions. The whole nation kept an eye on him?

Roosevelt made actions in two different senses, with great political instinct. On the one hand, he had direct relations with journalists and the media, which made him an important figure for the media at the time. On the other hand, he simultaneously opened important channels in order to know the opinion of the average American, before the modern-day poll companies were consolidated. This allowed Roosevelt to measure his country in a severe moment of socioeconomic crisis:

The president was the best source of information in the capital. He clearly understood what the journalists were demanding; he gave them so much information that they lacked the time to check with other sources... simultaneously, Roosevelt began his version of what we nowadays know as accountability, when he asked the citizens to send him letters about their concerns or needs, some of which were answered by the office of information. ${ }^{8}$

These actions were so important that they set a milestone in the current political communications. His radio show called The Fireside Chats, another of the communicational innovations made by Roosevelt, will be studied in the following pages.

\section{THE PRESIDENT IS THE MESSAGE}

As pointed out by the expert Roberto Izurieta, from the George Washington University in Washington, DC, the main communication resource of the governments is the president. And the best communication resource of the president is to turn directly to the public. This direct communication between the leader of the government and the citizens has different nuances depending on the media-related qualities of the chiefs of state, and on their relationship with the media system in their country. For the author, presidents have a direct communication platform with the citizens in different opportunities:

F. Noguera, 'La campaña permanente' in R. Izurieta, C. Arterton, R. Perina (comps.), Estrategias de comunicación..., p. 91.

H. Vega, 'La comunicación de gobierno..., p. 143.

8 Ibid.

9 R. Izurieta, 'La comunicación política en la era del entretenimiento. Un estudio de la comunicación y las relaciones públicas para gobiernos' in R. Izurieta, C. Arterton, R. Perina (comps.), Estrategias de comunicación..., p. 206. 
the annual speech to the nation, ceremonies, trips, any kind of speeches and, in the case of the United States of America, Saturdays on the radio. ${ }^{10}$ The last practice has been sort of passed on from generation to generation amongst American presidents ever since Franklin Delano Roosevelt started his Fireside Chats. As stated in previous paragraphs, Roosevelt had a great instinct in the subject of political communication, which lead him not only to establish these radio dialogues with regular citizens, but also to open the gates of the White House for Americans to let their president know about their problems and demands through letters and telegrams.

At the same time, Roosevelt completely turned around the public information office created by Woodrow Wilson in the White House, since he established distribution networks for press articles amongst hundreds of regional or local papers, which at the moment was a wonderful campaign of political government communication: at the end of his administration, the government's publicists would send a thousand newspaper articles written by expert former journalists with their own style and format, which needed very few or no changes at all. ${ }^{11}$ As stated by Izurieta, the image of a direct dialogue between the head of state and the citizens was reinforced with the television, arriving therefore the era of the image. Nixon's address as vice-president in 1952, known as the Checkers speech, set a milestone in this regard. This speech was aired directly in a blanket television broadcast and it was considered to be the salvation of his political career at the moment and the beginning of the practice and later trend of all presidents to turn directly to the public without going through journalists. ${ }^{12}$

The discussion about the role of a head of state in the communication area is not an exclusive matter of the last years, or of the particular case of Venezuela and its president Hugo Chávez. Chávez transmits an extremely long program "Aló Presidente" as well as frequent and lengthy national mandatory broadcasts, or blanket broadcasts, in radio and television. The communicational role of a president was already addressed by the American president Harry Truman (1945-1953), in a letter written to his sister: All the President is, is a glorified public relations man who spends his time flattering, kissing and kicking people to get them to do what they are supposed to do anyway" (Izurieta, 2005: 216). Modern society, characterized by the increase of mass media, reinforces the communicational feature of a nation's presidency. For Izurieta, it is difficult to know if a president's labor will be measured by his/her rhetorical ability (or public relations) or by his/her administration; so far, the evidence suggests both. ${ }^{13}$

According to this expert in political communication, the time dedicated to communication media by presidents and successful ministers is over 15 hours per week, without including the trips outside the capital or abroad, when normally the president travels accompanied by journalists and communication media. As stated in a report issued by the Organization for Economic Cooperation and Development (OECD), many presidents

\footnotetext{
10 Ibid.

11 H. Vega, 'La comunicación de gobierno..., p. 142.

12 R. Izurieta, 'La comunicación política..., p. 206.

13 Ibid., p. 216.
} 
organize their daily work agenda around the media. ${ }^{14}$ Aside from the time invested in direct contacts with the press or in public appearances, the president also spends a significant amount of time analyzing how to communicate a policy, or if a state policy should or not be implemented based on its correct communicability to the public. ${ }^{15}$ For this expert, whose theories are supported by reports and documents from other authors such as Samuel Kernell or Philip Lesly, most part of a president's time is spent in doing public relations. ${ }^{16}$

\section{HEGEMONY IN MOTION IN VENEZUELA}

The study of the role of communication in the Venezuelan government administration in recent years requires the consideration of the use given by President Hugo Chávez to the private and public media space, with unprecedented facts and figures in the country's democratic history. The official discourse discourages the political role of the private media while promoting - at the same time - the "State's media hegemony", a term coined by the former minister Andrés Izarra in January, 2007. Naturally, this leads the political and government action to the media area. ${ }^{17}$

The number of television media administered by the government increased significantly between 2002 and 2009; going from one single channel, Venezolana de Televisión, to seven: Venezolana de Televisión, TVES, Vive, ANTV, Ávila TV and Telesur (with two channels, one national and one international). The State handles three radio circuits with national broadcast (Radio Nacional de Venezuela, YVKE Mundial and Rumbos) and over 250 community radio stations, most of which are simple relays of the official line. In addition, there are three newspapers financed with public funds: Vea, El Correo del Orinoco and Ciudad CCS. According to Teodoro Petkoff, editor of the journal Tal Cual, the strategy of setting a communication hegemony has two different goals: on the one hand, to establish an enormous communication machine property of the State, which is discretionally handled by president Chávez; and to crush the independent media, on the other hand. ${ }^{18}$

Based on a text written by Marcelino Bisbal, the following pages will present a summary of the principal trends in the subject of communication policy carried out by the government of President Hugo Chávez in the period 1999-2009. Altogether, these trends could provide us with a different perspective: Venezuela's government has indeed defined public communication policies, but they are aimed at supporting the goal affirmed by Andrés Izarra, e.g., building the "State's media hegemony". These policies refer to a serious of actions sustained in time:

14 Ibid.

15 Ibid.

16 Ibid.

17 L. Weffer, 'El socialismo necesita una hegemonía comunicacional, El Nacional (Caracas), 15 January 2007, p. A-4.

18 T. Petkoff, 'Miedo a los medios', TalCual, 2 February 2010, p. 1. 
Uncontrolled use of blanket broadcasts by the president; degrading or threatening mentions of journalists and media owners; aggressions to reporters and camerapersons; direct attacks to media facilities; use of financial resources as means of pressure; ignorance of the interim measures in favor of communicators issued by the Inter American Commission on Human Rights; elimination of official propaganda from the media adverse to the government; lack of access to public information; information bias in the State's media. ${ }^{19}$

According to the investigator Silvia Cabrera, the audiovisual media in Venezuela has suffered a sort of metamorphosis by going from a mixed-unauthentic system to a mixed-authoritarian system. ${ }^{20}$

According to different media monitoring, official channels have had a noticeable political bias which could even be considered as political discrimination. Even though these media are owned by the State, and are therefore public, they ignore a part of Venezuelan society because of their disagreement with the project of "Bolivarian Revolution" lead by Hugo Chávez. A study made in 2004 by the investigator Bernardino Herrera from the Communications Investigation Institute of the Universidad Central de Venezuela (ININCO-UCV, for its Spanish abbreviation) proved that more than 70 percent of a regular day of programming in VTV, the main State channel, was formed by biased information-opinion, party-government propaganda and reruns of presidential addresses. ${ }^{21}$ Furthermore, a month after TVES was founded (the substitute of RCTV in the channel 2 signal of the open television spectrum) with the promise of creating a public service television channel; a two-day program analysis demonstrated that a new space had been added to the government's communication model:

The national government uses this channel with the purpose of spreading its political doctrine through the news, promotions and public institutions propaganda. This propaganda, which is constantly repeated in all the programs, is aimed at promoting the political indoctrination of the population, as well as aggravating the cult of Chavez's personality. ${ }^{22}$

Aside from the consolidation of a state media machine unknown to Venezuelan democratic history, President Chávez rules from the media dimension. According to the figures issued by Reporters without Borders, between the dates of February 2nd, 1999 and December 31st, 2008, President Chávez addressed the nation via national blanket broadcast of television and radio for a total of 1.179 hours, which equals 49 uninterrupted days of speeches (Reporters without Borders, 2009). This calculation

19 M. Bisbal, 'El Estado-Comunicador y su especificidad' in Comunicación. Estudios venezolanos de comunicación, № 134 (2006), pp. 60-73.

20 S. Cabrera, La agenda informativa de la televisión venezolana durante el golpe de Estado de abril del 2002. Un análisis bajo la dimensión informativa del proceso de Agenda Setting, Non-published Doctorate Thesis, University of Rostock, 2010.

21 A. Cañizález, 'Venezuela: El lejano servicio público' in M. Albórnoz, M. Cerbino (comps.), Comunicación, cultura y política, Quito 2008, pp. 67-78.

22 G. Hernández, 'Gubernamental TVES', Comunicación. Estudios venezolanos de comunicación, № 139 (2007), pp. 26-31. 
does not include the broadcast hours of the TV show "Aló, Presidente" ("Hello, Mr. President?") which is only aired in the official media network. However, the total on-air time is estimated to be a similar number to that of the national blanket broadcasts. In his televised speeches, the president makes announcements and even makes spontaneous decisions related to his administration, changes his ministers, scolds his collaborators, designs his party's strategic guidelines, indoctrinates his followers, etc. It is necessary to reinforce the warning of a political communications expert: One should not abuse the political blanket broadcasts, because the audience will get tired and they can become counterproductive. ${ }^{23}$

In another unprecedented fact in Venezuela and in the democratic Latin American countries, President Chávez rules from the media dimension to a great extent (during the decade of the 60's and the 70's, the Cuban president Fidel Castro also used the media extensively). With his show "Aló, Presidente" and his blanket broadcasts, Chávez has become sort of a "showman" who sings, recites, and tells anecdotes about his life. ${ }^{24}$ Additionally, as stated by some experts, he shows evident personality features reflecting narcissism and an obvious trend to use the first person personal pronoun: the characteristic "me-ism" of President Chávez's discourse. ${ }^{25}$

The investigation carried out by Bolívar in 1999 analyzed the speech during the Venezuelan head of state inauguration ceremony and compared it to his predecessors (Carlos Andrés Pérez and Rafael Caldera), the results evidenced a more-frequent use of the first-person personal pronoun than any other pronoun forms. In this sense, in his inauguration as the head of the State, Chávez used it in 44.8 percent, while Perez used it in a 20.7 percent and Caldera in a 29.4 percent. ${ }^{26}$

The statements made by Bolívar ${ }^{27}$ regarding the use of personal pronouns in the political arena must be mentioned in this subject. Quoting Wilson ${ }^{28}$, the former prime minister of Great Britain, Margaret Thatcher, only used the "I" pronoun in mainly three kinds of occasions: 1) to tell anecdotes and establish some rapport with her listeners, 2) to express "honesty", and 3) to express positive things. On the other hand, the use of "we" appeared when associated to organizations, persons and concepts. At the same time, the results obtained from analyzing other politicians indicate that the use of "we" can favor exclusively to indicate abstract concepts related to ideals, strength, justice and beliefs. Moreover, linguistic analysis indicate that the use of the first-person per-

23 R. Izurieta, 'La comunicación política..., p. 206.

24 S. de la Nuez Aránega, 'Venezuela: factores claves en el conflicto gobierno-medios', Revista Latina de Comunicación Social, Vol. 47 (2002), paragraph 29, at <http://www.ull.es/publicaciones/ latina/2002/latina47febrero/4714delanuez.htm>, 21 January 2010.

25 H. Koeneke, 'Personalidad presidencial y medios de comunicación social: el caso de Hugo Chávez', Nuevo Mundo, № 91 (2002), pp. 64-80.

26 Ibid.

27 A. Bolívar, 'La autorreferencia en la práctica discursiva de Rafael Caldera' in C. Kohn, Discurso Politico y Crisis de la Democracia. Reflexiones desde la filosofía social, la ética y el análisis del lenguaje, Caracas 1995.

28 Ibid., p. 95. 
sonal pronoun ("I") is more frequent in oral than in written speeches. ${ }^{29}$ In Venezuela, we agree with Koeneke in locating this "me-ism" in the narcissistic area. ${ }^{30}$

In several occasions during his extended administration, the head of the state sets out the guidelines, announces decisions and changes state strategies, which seems to take even his closest collaborators by surprise. From our point of view, the latter represents an official trend, and particularly in the figure of the president: many decisions affecting public policies are not necessarily included in the previously designed plans and programs; these decisions appear to be included within the logic of a television staging where the program's host (president Chávez) has enormous power to change the script, make announcements and make decisions without previous consensus of the government equipment. Personality politics in Venezuela have become evident under the aegis of Chávez, and his natural scenery of exposure is the small screen. Government's actions are developed starting from the symbolic, from the media space where important decisions for the nation are made.

\section{USE OF BLANKET BROADCASTS OF RADIO AND TELEVISION}

President Chávez aired his 2000th blanket broadcast of radio and television on February 2nd, 2010, precisely 11 years of his beginning in office. During his extensive administration, the Venezuelan head of state has spoken using this mechanism in average every other day. These blanket broadcasts, or cadenas (chains) as they are popularly called in Venezuela, prevent any other message to be issued on the national network of radio and television, both public and private. According to the Inter American Commission on Human Rights (IACHR), between February, 1999 and July, 2009 the Venezuelan media aired a total of 1.923 presidential blanket broadcasts, equivalent to 1252 hours, 41 minutes, which corresponds to 52 uninterrupted days of broadcasting the president's messages. ${ }^{31}$ This becomes a long monologue, which by definition prevents a political dialogue or debate, visibly affecting pre-election periods where a general weather of free deliberation should be promoted in a democratic society. ${ }^{32}$

Before Hugo Chávez arrived in office, the use of blanket broadcasts in Venezuela was limited to a reduced number of messages from the head of State throughout the year, the transmission of official acts in national holydays and the arrival of foreign dignitaries to the country. On February 2nd, 1999, the same day when Chávez entered in office, an unprecedented record was established in the country. Four presidential blanket broadcasts were transmitted for a total length of 8 hours and 14 minutes in the day-,

29 Ibid.

$30 \quad$ H. Koeneke, 'Personalidad presidencial..., p. 73.

31 Comisión Interamericana de Derechos Humanos, Democracia y Derechos Humanos en Venezuela, Washington: IACHR 2009, p. 407.

32 Reporteros sin Fronteras, 'Referéndum constitucional: un paisaje mediático ensombrecido por la polarización y el exceso de alocuciones presidenciales', 2009, at <http://www.rsf.org/Referendum-constitucional-un.html>, 21 January 2010. 
afternoon- and prime-time schedule; setting therefore the record of occupation of the TV screen in a free transmission of this kind..$^{33}$

As shown in Figure 1, there is an extensive use of the national radio and television blanket broadcasts as well as the extremely long Sunday program Aló, Presidente. This space is broadcasted by the State media network and by an increased number of private radio and television channels, becoming therefore a semi-blanket broadcast. Between 1999 and 2008, the president spoke for a total of 1.204 hours in his Sunday program, and an additional amount of 1.166 hours in national blanket broadcasts. The total of 2.370 hours in front of the cameras and microphones, which does not include other kinds of "special" transmissions with the head of State, is equal to 59 working weeks (with an 8 hours/day working journey). During these first 10 years of government, President Chávez has invested a little more than one year, in terms of working journey, merely in his interventions broadcasted via radio and television. Approximately $10 \%$ of his total government time has been invested to the media.

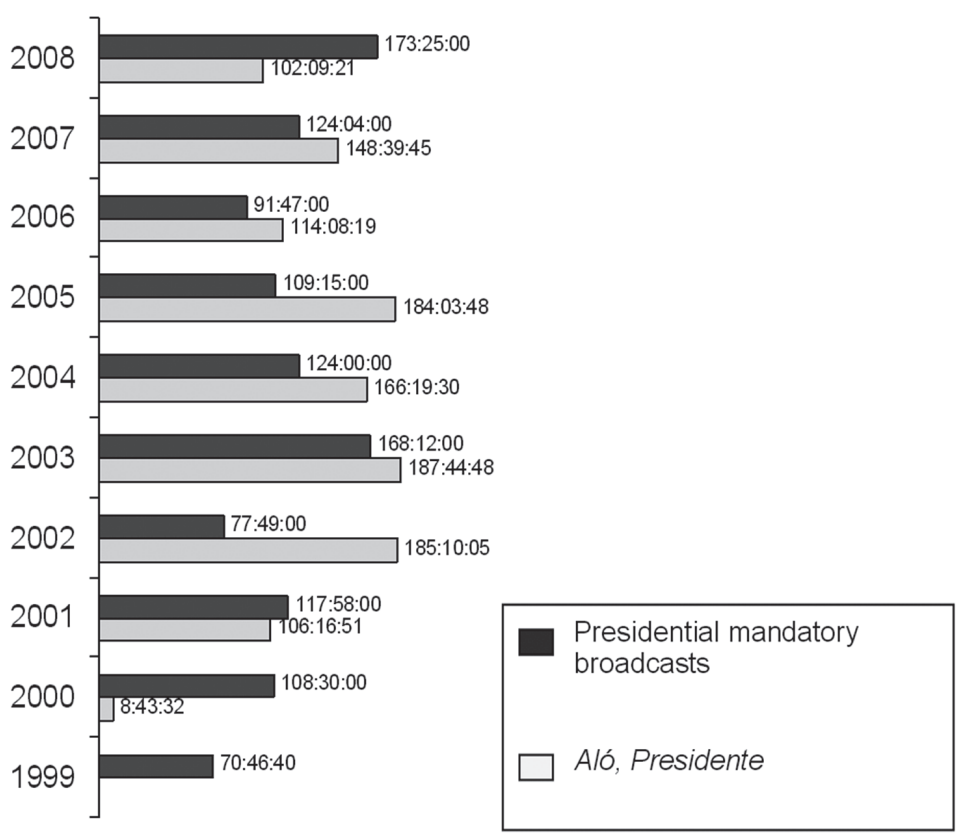

Figure 1. Historic registry of the radio and television blanket broadcasts - expressed in hours - transmitted between 1999 and 2000 (personal compilation). Radio emissions of the program Aló, Presidente for 1999 were not included; television programs aired between the years 2000 and August 2008 were included.

Blanket broadcasts have a clear impact in the political context and, in particular, during elections for several reasons. President Chávez uses a space that is property of the

33 AGB Nielsen Media Research, Horas de transmisión de las cadenas presidenciales y del programa Aló, Presidente, Caracas 2009. 
State - and therefore public - for his propaganda. Due to its public nature, this pace should be excluded from political disputes. He uses this mechanism in excess, which generates a distortion in the volume of official and opposition messages in a campaign. To end with, when President Chávez speaks nationally in blanket broadcasts, he cancels any other message, e.g., he restricts the possibility of Venezuelans to freely choose which points of view, which information or opinions to follow. It is a single message, a message from the president, which must be mandatorily heard by the rest of the country. As stated by the Inter American Commission on Human Rights (IACHR) in its documented report Democracy and Human Rights in Venezuela, there is a large number of blanket government broadcasts in the media in the country, which force media stations to cancel their regular programming and transmit information as ordered by the government, and Many of them were of a duration and frequency that could be considered abusive in light of the information they conveyed, not always intended to serve the public interest. ${ }^{34}$

Blanket broadcasts are often used for the president to participate in a political-electoral debate, despite the public nature of this instrument. Some examples in this regard were obtained from a review of the weeks prior to the constitution referendum made in February, 2009. In a national blanket broadcast of radio and television which aired on December 5th, 2008, the head of State appointed the managers for the campaign in favor of the "Yes" (in favor of a constitution amendment in order to permit the unlimited reelection of all elected offices):

I appoint Jorge Rodriguez (mayor of the Libertador council), Cilia Flores (President of the National Assembly) and Aristóbulo Istuiriz as the leaders. These are the first commissions of the campaign, which until the moment shall be called: "Uh, Ah, Chávez will not go!"35

This presidential announcement in the midst of an enthusiastic party speech had to be seen and heard mandatorily by the whole country.

On November 30th, 2008, the president also used a national blanket broadcast of radio and television in order to outline the political strategy of seeking his unlimited reelection:

After seeing what is happening and with a more clear view of the great threat that is looming the Venezuelan people with these fascists (to refer to the opposition), then, I say that you are right. "Uh, Ah, Chávez will not go! (...) I authorize the Socialist Unity Party of Venezuela and the Venezuelan people to start the debate and the actions to accomplish the constitutional amendment and the reelection of the president of the Republic, and I am sure that this time we are going to accomplish it. If God grants me the life and the health, God willing, I am ready to be with you until 2019, until 2021..$^{36}$

As stated by the organization Reporters without Borders, President Chávez, particularly within the context of elections, monopolizes the public speech with these blanket broadcasts, which have no apparent interest and/or utility. This highly acclaimed orga-

34 Comisión Interamericana de Derechos Humanos, Democracia y Derechos..., p. 407.

35 Reporteros sin Fronteras, 'Referéndum constitucional....

36 H. Lugo-Galicia, 'Chávez pidió al PSUV que promueva la enmienda, para la reelección', El Nacional (Caracas), 1 December 2008, p. A-2. 
nization in the democratic world considers an election campaign to be a privileged moment in the pluralism of opinions. The latter should be accomplished according to the principle of a fairly distributed time to speak, which should be guaranteed by the State. ${ }^{37}$ The use of blanket broadcasts is not only far from this fair distribution, but it also has an impact in the shape of public opinion.

In this context, the increasing use of blanket broadcasts of radio and television is evident in electoral times. A recall election for the president was carried out in Venezuela on August 15th, 2004. The month before elections (July, 2004) was precisely the month with the highest number of blanket broadcasts, the month of the electoral campaign. In that occasion, the president spoke for an average of 45 minutes per day with a single message, for a total of 22 hours. The disparity becomes evident when analyzing other months in the year 2004: for example, in January, the president only used 7 hours of blanket broadcasts, and in September, he used 4 hours for the whole month. ${ }^{38}$ Naturally, the number of blanket broadcasts and the moment for their use do not follow a guideline related to public interests.

Blanket broadcasts are clearly an official instrument during election campaigns. On January 13th, 2009, a few weeks before the referendum for approving a constitutional amendment, the longest presidential blanket broadcast for the 1999-2009 period was aired, it was seven hours and 34 minutes $^{39}$ of uninterrupted transmission. This is evidently a vast number of hours dedicated to the presidential monologue. As stated by the Inter American Commission on Human Rights Such figures do not include the transmission of the program "Aló Presidente", the ten minutes daily for governmental messages imposed by the Law on Social Responsibility in Radio and Television, or the official publicity that is typical in television or radio..$^{40}$

Moreover, the excessive use of radio and television blanket broadcasts by President Chávez does not appear to arise any concerns in other public powers. In November 2008, when the arrangements for the constitutional amendment referendum made in February 2009 were at the starting stage, the directorate of the National Journalistic Association went to the High Court of Justice in order to adhere to the writ of protection introduced by the organization Ciudadania Activa against presidential blanket broadcasts. Three spokespersons from the journalistic guild - Graciela Beltrán Carías, William Echeverría and Roger Santodomingo - expressed that the extended presidential addresses on air were an abuse against the Venezuelans' right to free information, and implied an interruption in the informative labor of journalists. Two weeks later, the Supreme Court pronounced a sentence where the lawsuit was expired due to the plaintiff's "lack of interest" ${ }^{\text {"31 }}$; without

37 Reporteros sin Fronteras, 'Referéndum constitucional..., para. 2.

38 AGB Nielsen Media Research, Horas de transmisión...

39 H. Lugo-Galicia, I. Artiaga, 'Chávez admite fallas y descarta estallido social', El Nacional (Caracas), 14 January 2009, p. A-2.

40 Comisión Interamericana de Derechos Humanos, Democracia y Derechos..., p. 407.

41 Tribunal Supremo de Justicia, 'Sentencia 01702 del 25.11.2008', 2008, para. 1, at < http://www.tsj.gov. ve/decisiones/spa/Noviembre/01702-251109-2009-2008-0872.html>, August 2010. 
pronouncing on the merits of the cause. The highest court acted very swiftly in order to leave the request without effect.

In the first 15 days of the 2010 parliamentary elections campaign, President Chávez was the figure with the most presence in radio and television media, although he was not a candidate and his position was not under elections. In accordance with a monitor made by the organization Sumate, the Venezuelan head of State spoke for an average offour hours per day in the first 15 official days of the election campaign. ${ }^{42}$ The transmissions of presidential acts by the State media network as well as the national blanket broadcasts of radio and television were included in this calculation. It is important to remember that the blanket broadcasts prevent the transmission of any other message through the system of radio and electronic media in Venezuela. Between August 25th (the official beginning of the campaign) and September 8th, the official media platform transmitted the supporting acts of the chief of State to the candidates of the Socialist Unity Party of Venezuela (PSUV, for its Spanish abbreviation) from eight different states in Venezuela, with an average of two hours per transmission. Although these acts were not aired via blanket broadcasts, they combined the complete network of official media such as Venezolana de Televisión (VTV), Asamblea Nacional Televisión (ANTV), Vive TV, Ávila TV and Radio Nacional de Venezuela (RNV). ${ }^{43}$

According to the organization Sumate, the remaining 16 acts were official addresses inherent to his investiture as head of State; however, in some of these acts, he continued with the electoral campaign, since he promoted PSUV candidates for representatives in the National Assembly and he spoke against the opposition. In order to do so, he made four national blanket broadcasts of radio and television, with an average of two hours of transmission, and thirteen transmissions and special programs, each one with an average of three hours each. ${ }^{44}$ This election-monitoring organization took the opportunity with the presentation of these figures to report the unresponsiveness of the National Elections Council (CNE, for its Spanish abbreviation) towards the open participation of the head of State in this campaign, and using public resources for this purpose. The directorate of the CNE, with the dissenting vote of Rector Vicente Diaz, ruled out any kind of punishment and/or sanction for President Chávez, by arguing that he had a right to manifest and express himself politically, beyond the limitations imposed by his presidential investiture. On June 23rd, 2010, the directorate of the CNE decided not to control the use of national blanket broadcasts of radio and television during the election campaign, following a sort of tradition which has become increasingly evident in the latter years, which diminishes the supervision power of the $\mathrm{CNE}$ on other public powers and, in particular, on the executive power.

42 A. Vásquez, J. Moronta, 'Chávez estuvo 63 horas en TV en los primeros 15 días de campaña', El Nacional (Caracas), 10 September 2010, p. A-2.

43 Ibid.

44 Ibid. 
These omissions of the electoral power permit President Chávez to use his appearances excessively on the system of radio and electrical media, and the campaign for the 2010 elections was not an exception. The president's repeated use of the media space generates a distortion in the volume of political messages, which notably favors the government and its candidates in the different election contests. Also, during the 2010 campaign, the head of State portrayed the role of a "super candidate", since his figure prevailed above the aspiring PSUV representatives to congress throughout the State-owned media network, evidently with the help of the national blanket broadcasts of radio and television.

\section{THE POPULIST MESSAGE}

As stated by Ramos Jiménez ${ }^{45}$, populism is not a new matter in Latin American policy nor in Venezuela, as demonstrated by Madriz, ${ }^{46}$ by comparing the figures of Rómulo Betancourt and Hugo Chávez. However, the new populist expressions "of the XXI century", as identified by the author, find a symbolically supporting branch in the radio and electronic media. In addition, we stated at the beginning of this paper that a dose of populism is inherent to the political action. These two lines of thought developed a difficulty in order to determine the populism degree in President Chávez's message, beginning from a quantification of determined phrases in the programs Aló, Presidente comprising the analyzed sample (2000, 2004 and 2006). In the text written by F. Welsch ${ }^{47}$, there was an idea developed by the author on the particularities of Chávez' populism, with three characteristics that could be transferred to a model of content analysis: the verb tense in which President Chávez builds his phrases. Due to the extensive and heterogeneous addresses of the head of State, this study only includes the phrases that were connected to public policies.

The reference to the present tense is notably diminished in presidential speeches, especially in the years 2000 and 2004, as appreciated in Table 1. The public criticism made by the head of State in his interventions after his reelection in December, 2006, explains the significant variation in the final year.

The president grants evident importance to those mentions related to the past in his media interventions. The phrases referring to the past are evidently found in the first place of the quantification of the three analyzed years, as evidenced in Table 1. After the analysis, it is important to make a distinction between the past and the recent past. The references in this investigation mostly include the phrases referring to the independent

45 A. Ramos Jiménez, 'Populismo del siglo XXI', Comunicación. Estudios venezolanos de comunicación, № 135 (2006), pp. 109-110.

46 A. Bolívar, "Cachorro del imperio" versos "Cachorro de Fidel": los insultos en la política latinoamericana', Discurso \& Sociedad, Vol. 2, № 1 (2008), at <http://www.dissoc.org/ediciones/v02n01/>, 31 January 2011.

47 F. Welsch, 'Populismo y cultura política en perspectiva comparada' in El Dorado. Sueños y realidades, Caracas 2007, pp. 98-103. 
struggle and to Simón Bolívar, in accordance to the approach explained in the beginning of this paper about the use of history in the political confrontation of the last decade. The registry of phrases mentioning the more-recent past, or what President Chávez colloquially calls the "4th Republic" was omitted.

Table 1: Populism in presidential messages of 2000, 2004 and 2006 (personal compilation)

\begin{tabular}{|c|c|c|c|}
\hline Category & 2000 & 2004 & 2006 \\
\hline Phrases referring to the past & $68 \%$ & $45 \%$ & $52 \%$ \\
\hline Phrases referring to the present & $8 \%$ & $10 \%$ & $20 \%$ \\
\hline Phrases referring to the future & $24 \%$ & $45 \%$ & $28 \%$ \\
\hline TOTAL & $100 \%$ & $100 \%$ & $100 \%$ \\
\hline
\end{tabular}

The head of state continuously established a parallelism between the independence quest and his government administration, even if they are not related, as in the following example when he includes his negotiations with the OPEC member countries as a reference point:

I know, and we know, and the Venezuelan people has given historical demonstrations of its solidarity, in such an extent that you, I mean, our people, this blood that runs through our veins has ran in Ayacucho, has ran in Pichincha, has ran in Junin and has ran in Boyaca. We, the Venezuelan people, went to liberate other countries without asking for anything in return, the glory of being useful, as Bolivar would say. Well, it is the same now, in this situation when, or in which we have recuperated the fair prices of our oil. ${ }^{48}$

Another communication strategy of President Chávez, within this populist dynamic, is the identification of Simon Bolívar not only as the father of the motherland, in that Bolivarian altar discussed in the initial pages of this paper, but also as the precursor of the "Bolivarian Revolution":

I recommend all of you, Venezuelan citizens, men, women, youths, and children, read Bolivar, discuss him in your families. You, as the head of the family, look for one of Bolivar's books, his speeches, so that we all understand the foundation, the essence of our revolution. There is no revolution without a revolutionary ideology, and ours is not imported from anywhere, our ideology was born right here, and not only from Bolivar, have we talked about Bolivar because he is the main exponent of an era. ${ }^{49}$

This message appears to be fixed amongst the followers of the head of State, along with a recurring historical reinterpretation made by the president in his interventions in order to link Bolívar with his political project:

48 H. Chávez, 'Aló Presidente 45', 2000, p. 14, at <http://www.alopresidente.gob.ve/materia_alo/25/p23/tp-27/>, 7 September 2010.

49 Idem, 'Aló Presidente 40', 2000, p. 52, at <http://www.alopresidente.gob.ve/materia_alo/25/p-23/ tp-27/>, 7 September 2010. 
José Rafael Torres (on the telephone from Punto Fijo): I have told my friends that you are so similar, because of your attitude... your work is very similar to the work of Bolivar, and I have come to think that Bolivar was pro-Chávez.

President Chávez: And he is our leader. I mean, when we read Bolivar we have to imagine that he is speaking, he left those words for us. ${ }^{50}$

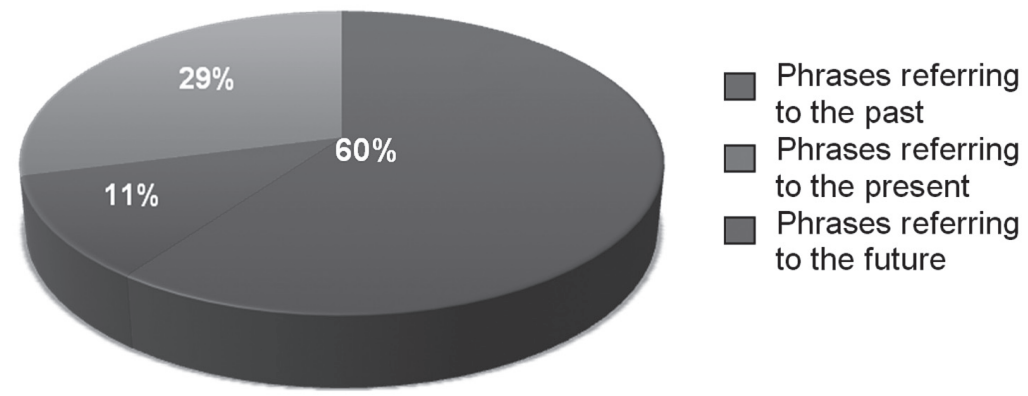

Figure 2. Total Populism in presidential messages 2000, 2004 and 2006 (personal compilation)

Figure 2 presents the totals in this section. The past symbolized in the quest for independence of the 19th century is a never ending source for the media message of President Chávez; in fact, it represents a significant majority with the 60 percent. The reference to the present is forgotten, intentionally avoided, because his speech is even focused in the announcement of what will be done in public policies. The announcement of a policy is the immediate future. However, there is a more distant and, at the same time, glorious future which precisely embodies a populist message in the presidential discourse:

But we have to build the kingdom of heaven here; the kingdom of happiness. Venezuela must be honorable again. Venezuela must be a country with a bright, honorable, happy, brotherly, supportive middle class, an example for America and the whole world. That is our direction; of course we are only in the beginning. The road is long, but we will do it. ${ }^{51}$

This elaboration of the temporary dimension in the presidential message cannot be considered as occasional and/or fortuitous. As previously stated, the present is avoided, and in the meantime, the current political process is reinterpreted as an inheritance of the Bolivarian quest, and serves as a pivot for projecting the future. The importance of each temporary dimension is not casual; President Chávez is aiming to insert his project as a fundamental part of Venezuelan memory in this century:

50 AGB Nielsen Media Research, 'Cadenas histórico minutos por año 1999-2008', 2008, at <http:// www.agbnielsen.com.ve/libro2008/CADENAS/HISTORICO.html>, 18 October 2010.

51 H. Chávez, 'Aló Presidente 44', 2000, at <http://www.alopresidente.gob.ve/materia_alo/25/p-23/ tp-27/>, 7 September 2010. 
History, the history that we are building. In a hundred years, our small children and the youths will be studying, well, the Venezuelan history of the 21st century, which will be very different than that of the 20th century, which is now over. The 21st century is open triumphantly for Venezuela with open skies and a blue horizon. Venezuela will be great again. ${ }^{52}$

As a conclusion, President Chávez's populist message is mainly supported by a discourse which focuses on the link between his government and the independence quest, with a special emphasis in the figure of Simon Bolivar. References to the present are absent or diminished. Moreover, the other populist component of the presidential discourse in the case of Hugo Chávez is the promise of a future of greatness for the nation.

\section{THE SELF-ORIENTED MESSAGE}

The exaltation of President Hugo Chávez's figure has been demonstrated with the content analysis of the Aló Presidente programs corresponding to the sample (2000, 2004 and 2006). Based on the considerations made by Koeneke - quoting Bolívar - in relation to the presidential personality politics, an instrument was design in order to quantify the number of times the head of State speaks in the first-person form, by using the pronoun "I", when he uses the pronoun "we". After a first review of the messages, a third category was added: "Chávez" which refers to the moments when the president speaks about himself in the third-person singular. Due to the heterogeneity of topics discussed by the president, only those phrases related to the creation, implementation and/or evaluation of public policies were selected. The many references made by the president about his life and personal history have been excluded from this analysis. On a side note, it is important to mention that the self-oriented phenomenon is not particular of Venezuela, since Latin American governments show a distinct personality-oriented trend.53

Table 2 evidences the wide predominance of the self-oriented "I" in President Chávez's addresses when speaking about public policies in the three years under analysis. This trend became more distinct in the year 2000, and even though it decreased in 2004 and 2006, it is still the principal subject in his discourse when referring to government actions. The topic of self-orientation has already been commented in previous pages since, inevitably, the President refers to himself in different contexts. The phrase "I have decided" was evidenced to be very present in the expression and messages of the head of state:

I ordered an investigation about all of that, and I want results, because we made an assembly with the neighbors, I went there. We are also neighbors from the Miraflores area. Then we made a ceremony in the Municipal Theater, the project was exposed and I appro-

52 Idem, 'Aló Presidente 45', 2000, p. 61, at <http://www.alopresidente.gob.ve/materia_alo/25/p-23/ tp-27/>, 7 September 2010.

53 A. Bolívar, “'Cachorro del imperio”..., p. 10. 
ved something like 8 thousand million Bolivars for this project and nothing has been made in three years. ${ }^{54}$

Table 2. Self-orientation in presidential messages 2000, 2004 and 2006 (personal compilation)

\begin{tabular}{|c|c|c|c|}
\hline Category & 2000 & 2004 & 2006 \\
\hline I & $71 \%$ & $54 \%$ & $55 \%$ \\
\hline We & $20 \%$ & $28 \%$ & $32 \%$ \\
\hline Chávez & $9 \%$ & $18 \%$ & $13 \%$ \\
\hline TOTAL & $100 \%$ & $100 \%$ & $100 \%$ \\
\hline
\end{tabular}

As observed in Figure 3, in general the "I" represents 64 percent of the quantified messages, but if the referrals to Chávez when the president speaks about himself in the third person are added, then the total represents 74 percent. This means that three out of every four times the president is speaking about public policies, he mentions himself. This personalization in the political decisions and mends in some cases are opposed to dispositions made by other officers who have been equally elected by the people:

Over there, next to the Mayor Office of Caracas, they started to make a huge thing, I told them to stop and had it torn down, but they haven't done it. Freddy (Bernal), the other day I was telling Adán (Chávez): Adán, I am going to have to bring a battalion of soldiers, I am capable of doing it, but I don't want to go over you. Dismantle that thing from there, because nobody told me and that is very close to Miraflores. A horrible thing, a big, ugly thing, I don't even know what it is for, awful, awful..$^{55}$

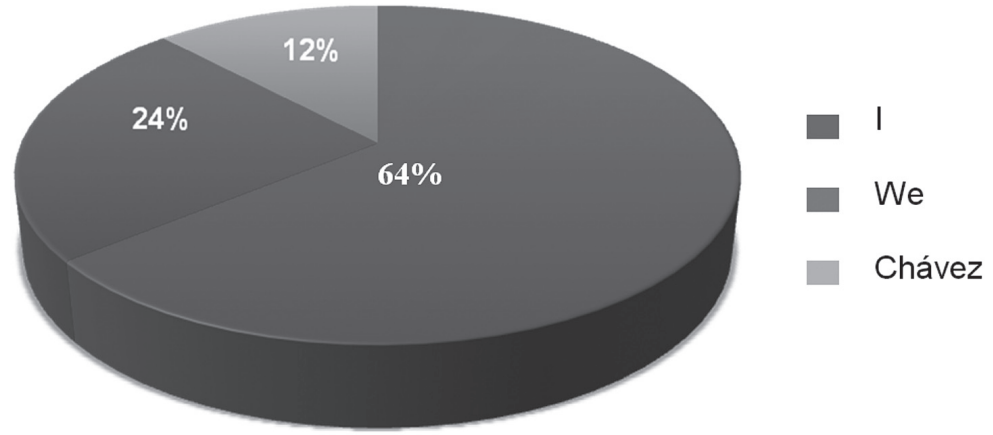

Figure 3. Total Self-orientation in presidential messages 2000, 2004 and 2006 (personal compilation)

54 H. Chávez, 'Aló Presidente 204', 2004, p. 11, at <http://www.alopresidente.gob.ve/materia_alo/25/ p-23/tp-27/>, 7 September 2010.

55 AGB Nielsen Media Research, 'Cadenas histórico minutos.... 
President Chávez often merges his personal stories to the history of national and/or international events, even if he had no personal participation in them. This is another expression of a self-orientation bordering on narcissism, as stated by (2002). An example in this regard is found in his welcome message to the delegations of the Organization of the Petroleum Exporting Countries:

Let us welcome the many delegate men and women from our brother OPEC countries, they are all our brothers. From an organization founded forty years ago, in which Venezuela played an important role in its foundation: the OPEC. It was 1960 and precisely here in Venezuela the statutes of the OPEC were approved in that year, 1960. I was 6 years old. ${ }^{56}$

The president's self-oriented message, as it has been stated before, uses alternatively the pronoun "I" and the reference to "Chávez" in the third person. This is a task for the message analysis field, and therefore, further evaluations are not viable (for example, psychological and/or psychiatric) about this type of expression. However, this is a clearly appealing aspect of the presidential discourse, given its constant presence:

Something like five thousand years ago I went to Zaraza to a Bolivar plan, and people would say to me: Chávez, we don't have water, Chávez, there is no water. Well, ever since, although we brought the news, we discussed it, we sought the resources and made a decision, Zaraza is still the same, it has no water. ${ }^{57}$

There is an enormous danger for democratic governability in the fact that public decisions, with impact on the whole society, are characterized by a personal seal from the president. We found a clear example in the following announcement of the head of State after his reelection in December, 2006:

And to burt you, although I really don't do it just to hurt you, I don't care if it hurts you or not, but I know that it will hurt you: next Sunday we won't have Aló Presidente, we will have a military parade for commemorating the 15th year anniversary of the military rebellion of February 4th, Bolivarian rebellion. ${ }^{58}$

In this final section of the present chapter, the notable imbalance prevailing in presidential messages have been evidenced, with a major proclivity towards a self-orientation of the head of State. This exaltation of Hugo Chávez's figure darkens the isolated sparkles of programmatic elaboration, implementation and evaluation of public policies in Venezuela, under the seal of "Bolivarian Revolution".

\section{REFERENCES}

AGB Nielsen Media Research, 'Cadenas histórico minutos por año 1999-2008', 2008, at < http:// www.agbnielsen.com.ve/libro2008/CADENAS/HISTORICO.html>, 18 October 2010.

56 H. Chávez, 'Aló Presidente 44', 2000, p. 4, at <http://www.alopresidente.gob.ve/materia_alo/25/p23/tp-27/>, 7 September 2010.

57 Idem, 'Aló Presidente 204', 2004, p. 12, at <http://www.alopresidente.gob.ve/materia_alo/25/p-23/ tp-27/>, 7 September 2010.

58 AGB Nielsen Media Research, 'Cadenas histórico minutos....' 
AGB Nielsen Media Research, Horas de transmisión de las cadenas presidenciales y del programa Aló, Presidente, Caracas 2009.

Berrocal S., 'Una aproximación a la nueva retórica del líder político televisivo: acciones, cualidades y discurso', DOXA Comunicación, № 2 (2004), pp. 53-67.

Bisbal M., 'El Estado-Comunicador y su especificidad', Comunicación. Estudios venezolanos de comunicación, No 134 (2006), pp. 60-73.

Bisbal M., 'Redescubrir el valor del periodismo en la Venezuela del presente' in M. Marrero, R. Martínez Iglesia (coords.), Comunicación y Libertad, Caracas 2006, pp. 81-106.

Bolívar A., "Cachorro del imperio" versos "Cachorro de Fidel”: los insultos en la política latinoamericana', Discurso \& Sociedad, Vol. 2, No 1 (2008), at <http://www.dissoc.org/ediciones/ v02n01/>, 31 January 2011.

Bolívar A., 'El personalismo en el discurso político venezolano', ponencia presentada en el XXVII Congreso Interamericano de Psicología, Caracas 1999.

Bolívar A., 'La autorreferencia en la práctica discursiva de Rafael Caldera' in C. Kohn, Discurso Político y Crisis de la Democracia. Reflexiones desde la filosofía social, la ética y el análisis del lenguaje, Caracas 1995.

Cabrera S., La agenda informativa de la televisión venezolana durante el golpe de Estado de abril del 2002. Un análisis bajo la dimensión informativa del proceso de Agenda Setting, Non-published Doctorate Thesis, University of Rostock, 2010.

Cañizález A., 'Un año sin RCTV', Tal Cual, 28 May 2008, p. 23.

Cañizález A., 'Venezuela: El lejano servicio público' in M. Albornoz, M. Cerbino (comps.), Comunicación, cultura y política, Quito 2008, pp. 67-78.

Comisión Interamericana de Derechos Humanos, Democracia y Derechos Humanos en Venezuela, Washington: IACHR 2009.

Durán J., 'Estrategias de comunicación política' in R. Izurieta, C. Arterton, R. Perina (comps.), Estrategias de comunicación para gobiernos, Buenos Aires 2005, pp. 23-76.

Hernández G., 'Gubernamental TVES', Comunicación. Estudios venezolanos de comunicación, No 139 (2007), pp. 26-31.

Izurieta R., 'La comunicación política en la era del entretenimiento. Un estudio de la comunicación y las relaciones públicas para gobiernos' in R. Izurieta, C. Arterton, R. Perina (comps.), Estrategias de comunicación para gobiernos, Buenos Aires 2005, pp. 187-525.

Koeneke H., 'Personalidad presidencial y medios de comunicación social: el caso de Hugo Chávez', Nuevo Mundo, No 91 (2002), pp. 64-80.

Lugo-Galicia H., 'Chávez pidió al PSUV que promueva la enmienda, para la reelección', $E l$ Nacional (Caracas), 1 December 2008, p. A-2.

Lugo-Galicia H., I. Artiaga, 'Chávez admite fallas y descarta estallido social', El Nacional (Caracas), 14 January 2009, p. A-2.

Noguera F., 'La campaña permanente' in R. Izurieta, C. Arterton, R. Perina (comps.), Estrategias de comunicación para gobiernos, Buenos Aires 2005, pp. 77-102.

Nuez Aránega S. de la, 'Venezuela: factores claves en el conflicto gobierno-medios', Revista Latina de Comunicación Social, Vol. 47 (2002), at <http://www.ull.es/publicaciones/ latina/2002/latina47febrero/4714delanuez.htm>, 21 January 2010.

Petkoff T., 'Miedo a los medios', TalCual, 2 February 2010, p. 1. 
Ramos Jiménez A., 'Populismo del siglo XXI', Comunicación. Estudios venezolanos de comunicación, $\mathrm{N}^{\circ} 135$ (2006), pp. 109-110.

Reporteros sin Fronteras, 'Referéndum constitucional: un paisaje mediático ensombrecido por la polarización y el exceso de alocuciones presidenciales', 2009, at <http://www.rsf.org/ Referendum-constitucional-un.html>, 21 January 2010.

Tribunal Supremo de Justicia, 'Sentencia 01702 del 25.11.2008', 2008, at <http://www.tsj.gov. ve/decisiones/spa/Noviembre/01702-251109-2009-2008-0872.html>, August 2010.

Vásquez A., J. Moronta, 'Chávez estuvo 63 horas en TV en los primeros 15 días de campaña', El Nacional (Caracas), 10 September 2010, p. A-2.

Vega H., 'La comunicación de gobierno e Internet' in R. Izurieta, C. Arterton, R. Perina (comps.), Estrategias de comunicación para gobiernos, Buenos Aires 2005, pp. 131-186.

Weffer L., 'El socialismo necesita una hegemonía comunicacional', El Nacional (Caracas), 15 January 2007, p. A-4.

Welsch F., 'Populismo y cultura política en perspectiva comparada' in El Dorado. Sueños y realidades, Caracas 2007, pp. 98-103.

\section{Sources of the Sample under Analysis}

\section{Aló, Presidente year 2000}

Chávez H., 'Aló Presidente 40', 2000, at <http://www.alopresidente.gob.ve/materia_alo/25/ $\mathrm{p}-23 / \mathrm{tp}-27 />, 7$ September 2010.

Chávez H., 'Aló Presidente 44', 2000, at <http://www.alopresidente.gob.ve/materia_alo/25/ $\mathrm{p}-23 / \mathrm{tp}-27 />, 7$ September 2010.

Chávez H., 'Aló Presidente 45', 2000, at <http://www.alopresidente.gob.ve/materia_alo/25/ $\mathrm{p}-23 / \mathrm{tp}-27 />, 7$ September 2010.

Chávez H., 'Aló Presidente 46', 2000, at <http://www.alopresidente.gob.ve/materia_alo/25/ $\mathrm{p}-23 / \mathrm{tp}-27 />, 7$ September 2010.

\section{Aló, Presidente year 2004}

Chávez H., 'Aló Presidente 201', 2004, at <http://www.alopresidente.gob.ve/materia_alo/25/ $\mathrm{p}-23 / \mathrm{tp}-27 />, 7$ September 2010.

Chávez H., 'Aló Presidente 202', 2004, at <http://www.alopresidente.gob.ve/materia_alo/25/ $\mathrm{p}-23 / \mathrm{tp}-27 />, 7$ September 2010.

Chávez H., 'Aló Presidente 203', 2004, at <http://www.alopresidente.gob.ve/materia_alo/25/ $\mathrm{p}-23 / \mathrm{tp}-27 />, 7$ September 2010.

Chávez H., 'Aló Presidente 204', 2004, at <http://www.alopresidente.gob.ve/materia_alo/25/ $\mathrm{p}-23 / \mathrm{tp}-27 />, 7$ September 2010.

\section{Aló, Presidente year 2006}

Chávez H., 'Aló Presidente 263', 2006, at <http://www.alopresidente.gob.ve/materia_alo/25/ p-23/tp-27/>, 16 September 2010.

Chávez H., 'Aló Presidente 264', 2006, at <http://www.alopresidente.gob.ve/materia_alo/25/ p-23/tp-27/>, 16 September 2010. 
Chávez H., 'Aló Presidente 265', 2006, at <http://www.alopresidente.gob.ve/materia_alo/25/ p-23/tp-27/>, 16 September 2010.

Chávez H., 'Aló Presidente 266', 2006, at <http://www.alopresidente.gob.ve/materia_alo/25/ p-23/tp-27/>, 16 September 2010.

Andrés CAÑIZÁLEZ, Venezuelan. Doctor in political science with post-graduate studies in Venezuelan history and a bachelor's degree in Social Communications. Professor - investigator with partnership level in the Universidad Católica Andrés Bello (UCAB), member of the Communications Investigation Center (CIC) where he coordinates the "Comunicación y Democracia" Program (Communications and Democracy). He has published different academic texts on the subject of freedom of expression, media and democracy, for publications in Latin America and Europe. He coordinates the Political Communications work group of the Latin American Association of Communication Investigators (ALAIC, for its Spanish abbreviation) and he is the vice-president of the Venezuelan Association of Communication Investigators (INVECOM, in Spanish). He regularly writes in the Venezuelan journals: El Nacional, Tal Cual and El Tiempo. He directs the magazine Temas de Comunicación. 